Article

\title{
Impact of Cruise Activity on Freshwater Use in the Port of Palma (Mallorca, Spain)
}

\author{
Celso Garcia ${ }^{1}(\mathbb{D})$, Christian Mestre-Runge ${ }^{2}\left(\mathbb{D}\right.$, Enrique Morán-Tejeda ${ }^{1, * \mathbb{D}}$, \\ Jorge Lorenzo-Lacruz ${ }^{3}{ }^{-1}$ and Dolores Tirado ${ }^{4}$ \\ 1 Department of Geography, University of the Balearic Islands, 07122 Palma, Spain; celso.garcia@uib.es \\ 2 Department of Horticulture, Fruit Growing Botany and Gardening, University of Lleida, 25198 Lleida, Spain; \\ cristian.mestre@hbj.udl.cat \\ 3 Department of Human Sciences, University of La Rioja, 26006 Logroño, Spain; jorge.lorenzo@unirioja.es \\ 4 Department of Applied Economics, University of the Balearic Islands, 07122 Palma, Spain; \\ dolores.tirado@uib.es \\ * Correspondence: e.moran@uib.es; Tel.: +34-971-173482
}

Received: 4 February 2020; Accepted: 9 April 2020; Published: 11 April 2020

check for updates

\begin{abstract}
Lack of knowledge about freshwater use in ports of tourist destinations hinders accurate assessment of water availability and water planning. In this study, freshwater use in the Port of Palma (Spain) is analyzed by sector (commercial, mixed, navy and recreational) for the period 2007-2018. This study shows the dynamics of consumption and evaluates the effects of increased cruise tourism from 2007 to 2018 in the port. Water data supplied by the Port Authority of the Balearic Islands for each sector, together with water volumes recharged by ships, allow a detailed analysis of the water used by merchants and cruise lines. Results reveal a significant increase in freshwater withdrawals by cruise ships in the Port of Palma in the last ten years, closely related to the boom of cruise activity. Water use and recharge by cruise ships increased in both the high and low tourist seasons. Homeport cruises have a significant effect on the increase of freshwater withdrawals, as each homeport cruise ship recharged a mean volume of $628 \mathrm{~m}^{3}$ per mooring. This paper proposes a water withdrawal indicator of liters loaded per passenger at the port. Given the current lack of restriction on the number of cruise ships per day docking in the Port of Palma, cruise activity may well become a threat to water availability during drought episodes and another environmental cost to add to the already questioned cruise tourism activity of the island.
\end{abstract}

Keywords: cruise tourism; freshwater withdrawals; Port of Palma; Mediterranean

\section{Introduction}

Freshwater supply was not one of the top 10 environmental priorities of European ports for 2018 [1], and it has not been a priority since 1996, when water was considered an environmental issue (or constraint) for port development [2]. The first three priorities for port authorities have been the same since 2016: air quality, energy consumption and noise. However, freshwater withdrawal is one of the environmental monitoring indicators reported by $72 \%$ of European ports in 2018 , the fourth behind waste, energy consumption and water quality [1].

Mediterranean ports have witnessed an important increase in the cruise tourism industry over the last 15 years [3]. Although it is recognized as a dynamic sector with economic benefits, it also has social and environmental costs [4-10], with historical town centers and tourist resources overwhelmed by massive numbers of tourists in just a few hours [11]. The Mediterranean Sea is the second most travelled area in cruise routes after the Caribbean. In 2018, the 10 major MedCruise Ports, in terms of cruise passengers, hosted a total of 17 million passenger visits and had 5875 cruise berths, increasing 
$10.4 \%$ and $3.6 \%$, respectively, compared with the previous year [12]. The Balearic Islands reached first position among visited Mediterranean ports in 2018, with 859 cruise berths, a $26.7 \%$ increase over 2014; and it was the third top destination in 2018, with 2,431,153 total cruise passenger visits, increasing $53.2 \%$ in the last four years. This archipelago also tops the list of main European cruise ports classified as scale (stopover included in an itinerary). In 2018, it received 1.57 million passengers, and, from 2014 to 2018 , the number of passengers increased $60.4 \%$. As a homeport (departure and/or end point of the cruise itinerary), it received around 850,000 passengers in 2018, 41.5\% more than in 2014 [12], as it holds a competitive advantage in attracting homeport traffic through a specialization strategy [13].

Despite the large freshwater volume required by ships in general, and cruises in particular, there is a lack of information, from a scientific view, on the impact this activity may have on freshwater resources, as there are no references to this topic in the relevant literature. Regardless of the many areas of interest, the number of scientific papers addressing cruise tourism does not match the importance of this type of tourism [14]. Although cruise tourism can be studied from the aspect of environmental impact caused by the number and size of ships and the cultural implications on destination ports [15], there has been no research done on the implications of cruise tourism on freshwater resources.

It is recognized that these luxury floating cities consume more resources than normal consumption patterns [16], and this overconsumption creates pressure in areas with fewer freshwater resources, but there is no literature specific to the cruise industry [17]. Some of the main cruise lines report water withdrawal per guest night on board [18], trying to reduce environmental impact and being socially responsible, but there is a lack of transparency regarding how much water they recharge at home ports. This is especially critical in small ports or islands with limited freshwater resources where, on heavy cruise days, the water demand increases [19]. There is a need to specify a water consumption indicator for cruise water consumption at ports that will allow comparison to local consumption volumes, in order to identify potential conflicts [19].

However, this is not an easy task; there is difficulty obtaining water use data from ports due to a lack of transparency in data management and the management of freshwater in ports. For example, in Spain, water is supplied by the water company to the port authority, and they sell part of this water to cruise and ferry vessels. Such gaps in knowledge may affect the capacity of water managers to accurately account for all water uses taking place in the territory and, consequently, in the design of sustainable water planning. This can be especially relevant in sensitive areas with inherent freshwater availability issues, such as the Balearic Islands [20-22].

Water supply in these Mediterranean islands has been negatively impacted by the rapid development of tourism, with an increase of residential and seasonal population [23-25]. This may all be aggravated by the consequences of climate change in the region. Projections show a decrease in freshwater availability due to decreasing precipitation and increasing evapotranspiration [26,27], with Mediterranean islands among the areas expected to be particularly affected by these changing conditions [28].

Given the background, this study proposes the first assessment of water use by ports, in the context of increasing cruise activity in a hot-spot area of both tourism increase and freshwater vulnerability. From the five ports of the Balearic Islands, the Port of Palma was selected because it is the largest and is a world leader in cruise passenger traffic. It is well equipped to play host to the world's largest cruise ships [29]. The island received 11,950,342 tourists in 2018, with 10.4 million people from other countries. The highest number of people on the island was recorded on 7 August 2018 at 1,457,173 [30].

The aim of this paper is to show the dynamics of water use in the port and its service areas between 2007 and 2018, and to outline how the increase in cruise ships and passengers have affected the water supply in the port of the city of Palma, one of the main touristic destinations in the Mediterranean with limited freshwater resources. 


\section{Study Area}

The Port of Palma is a commercial, passenger, recreational and fishing port located in the city of Palma (Mallorca, Balearic Islands, Spain) in the western sector of the Mediterranean Sea (Figure 1). Since the middle of the 20th century, this port has been managed by the Port Authority of the Balearic Islands (APB) and has undergone continuous expansion, adapting to the requirements of nautical tourism and the transit of goods and passengers. The current land area, water areas and depot areas are $340 \mathrm{ha}$, with $13.7 \mathrm{~km}$ of berthing length and a maximum draught of $16 \mathrm{~m}$. The entrance to the port is oriented ENE, with a width of $790 \mathrm{~m}$ [29].

The Port of Palma is the main point of entry and exit of goods from Mallorca, with more import than export. The imbalance between imports (69.5\%) and exports (30.5\%) [29] characterizes Mallorca as an island dependent on foreign trade, due to the effect of insularity. Historical series of mercantile data indicate the port has experienced significant growth since 1994, especially in the general goods market. Conversely, the percentage variation ratio indicates a decrease in the cargo derived from solid and liquid goods since 2005. This port is well connected with other national ports (Barcelona, Valencia, Ibiza, Mahon, Dénia) by some regular lines. Regarding Atlantic and Mediterranean cruise lines, Palma has positioned itself as a hybrid cruise port (homeport and transit) due to its functional capacity (transport services, intermediation services, hotels, port and land services such as water supply, grey water and solid waste collection, etc.) [31], and also due to its adequate port infrastructure (passenger terminal, quay length for berthing and unberthing of cruise ships). In addition, factors such as the connectivity between the port and the international airport of Palma via major roads, plus its geographical location (less than two hours by plane from central Europe), make Palma a favored homeport for cruise ships.

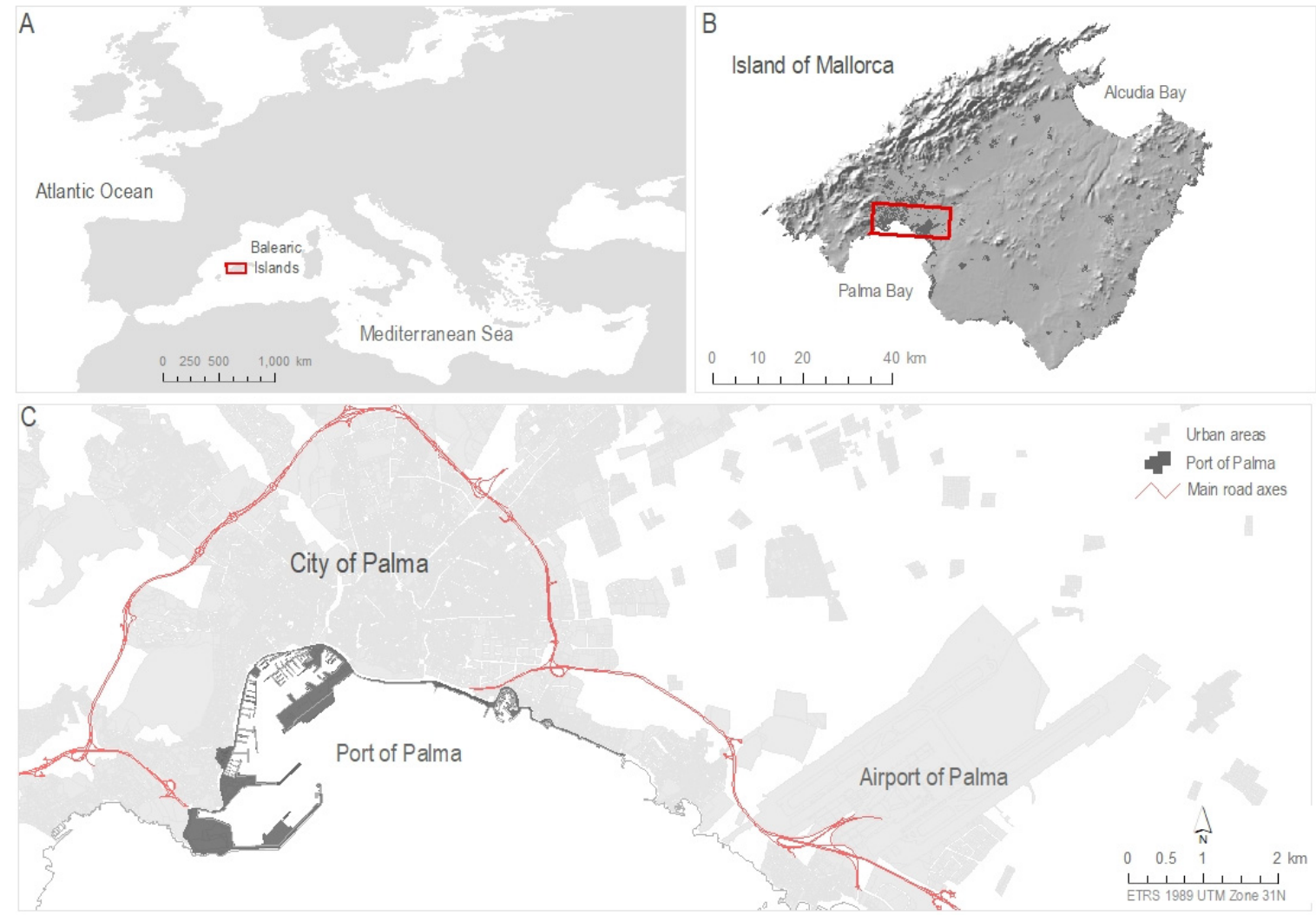

Figure 1. Location of the Port of Palma in (A) the western Mediterranean, (B) the island of Mallorca and $(\mathrm{C})$ the city of Palma and its connection with the airport. 


\section{Materials and Methods}

High spatial resolution cartography was carried out using a Geographic Information System (GIS) to characterize the functionality of the Palma port. Using spatial data from the National Geographic Institute of Spain [32] and high-resolution orthophotography (year 2018, geometric resolution $15 \mathrm{~cm} /$ pixel), the service areas of the port were digitalized. The various port activities were digitalized and geolocated using information provided by the APB's Environmental Sustainability Report [29].

In each commercial and naval station wharf, APB has water intakes to supply freshwater to merchant, warfare, service vessels and land services. Its freshwater supply capacities vary from $12 \mathrm{~m}^{3}$ /hour/quays to $720 \mathrm{~m}^{3}$ /hour/quays. APB also supplies freshwater to recreational, fishing and complementary services areas. In order to obtain water use by sector in the Port of Palma, the activities were classified in four categories: commercial, mixed, navy and recreational. The commercial category includes ferries and cruise lines, and the mixed sector includes ship repairs, local traffic and services, land services, tugs and various, Ro-Ro, ship repairs and tugs, and shipyards (Figure 2).

The APB has eleven water meters that record water consumption at these areas. Water is supplied by Palma's municipal water company EMAYA. All water volumes, registered at each water meter in a bimonthly bill, were ceded by the APB for the period 2008-2018 and were seasonally aggregated using high (May through October) and low (November through April) tourist seasons as reference.

Basic data plotting was done to visualize the evolution of water use in the Port of Palma, and the Mann-Kendall test, with pre-whitening auto-correlation algorithm removal [33], was applied to data to explore for significant monotonic trends during the study period.

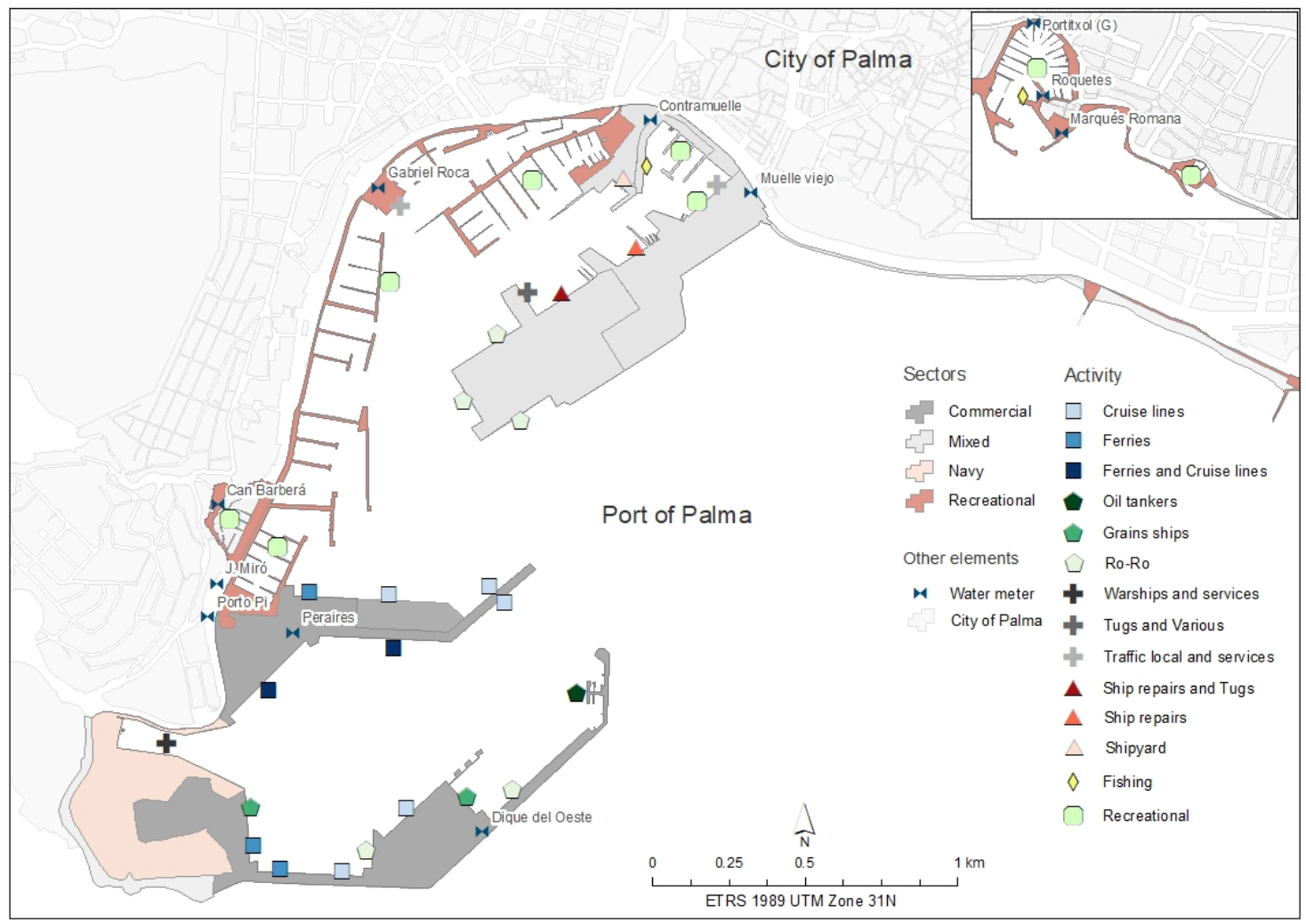

Figure 2. Classification of sectors in the Port of Palma according to activities and linked to the water meters installed.

One of the main difficulties of data collection was to obtain water withdrawal by ship typology. This research in the Port of Palma required contact with several companies to obtain some data on water recharge by their ships during stays in the port. These data further helped to interpret these results. 


\section{Results}

\subsection{Evolution of Water Use in the Port of Palma by Sectors}

Water withdrawal in the four sectors showed a clearly seasonal pattern, with a maximum peak during the high tourist season period (May-October) and a minimum during the low tourist season period (November-April) (Figure 3A), although differences between high and low seasons were not equal amongst sectors. The commercial sector was the largest consumer during the period 2007-2018 but also showed more seasonal dependence. The mixed sector showed less difference between seasons and, consequently, larger consumption than the commercial sector during the low season. It also showed more interannual variability, as indicated by the length of boxes and whiskers of the boxplot. The recreational and the navy sectors showed the lowest and least variable water withdrawal but still with differences between the two seasons.

A

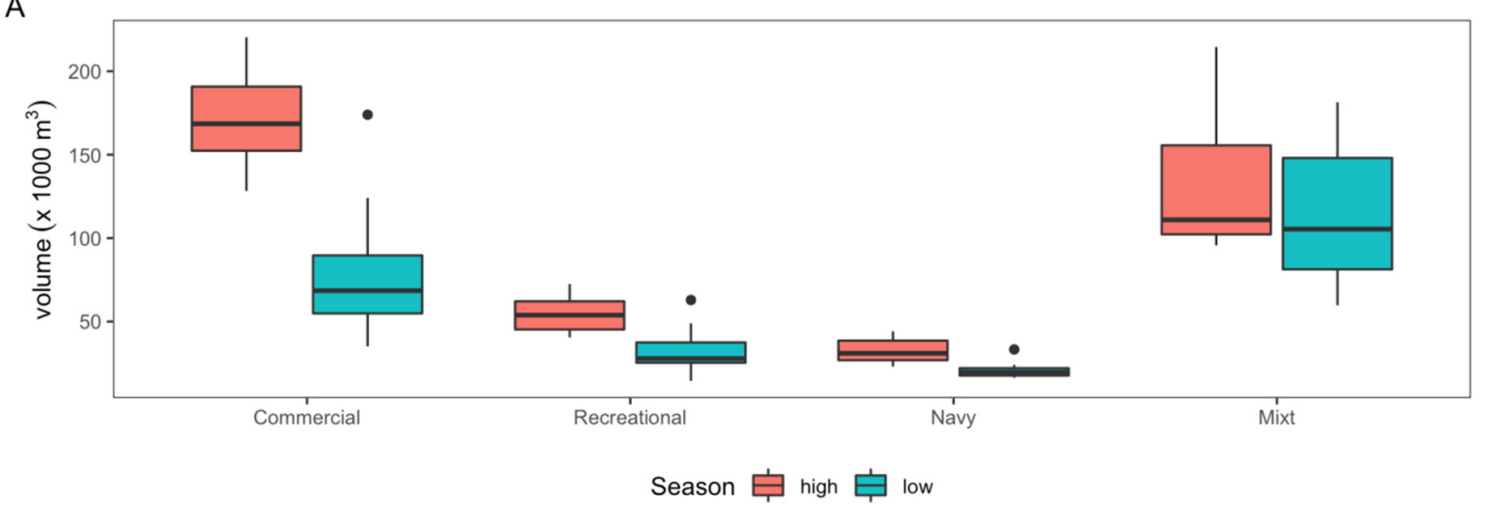

B
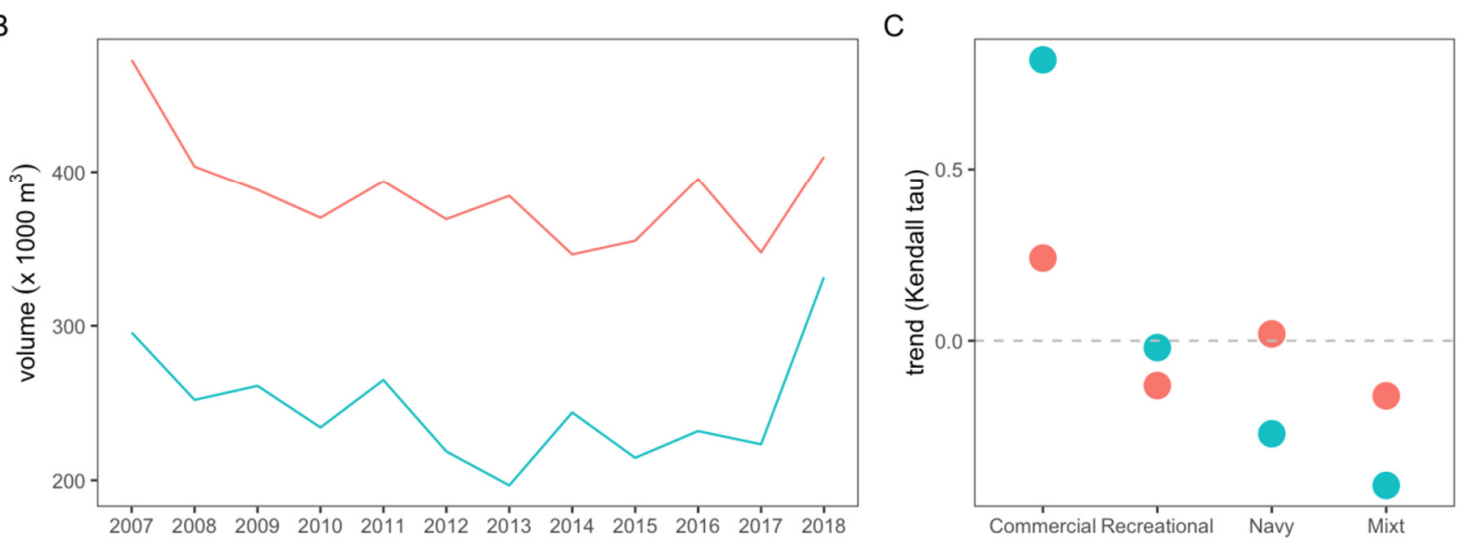

Figure 3. (A) Boxplots showing the distribution of water use by sectors and seasons during the period 2007-2018. (Solid lines: median; boxes: first and third quartiles; whiskers: 10th and 90th percentiles; dots: 5th and 95th percentiles). (B) Trend of temporal evolution for the period 2007-2018 of water withdrawals for the high and low tourist seasons. (C) Results of the Mann-Kendall trend test in the four sectors, classified by high and low tourist season, with y axis showing Kendall tau coefficient.

The temporal dynamic of the total water consumed by the Port of Palma for the high and low seasons showed a general decrease since 2007 (Figure 3B), showing minimum consumption in 2013-2014. However, the general reduction in the consumed water had some peak values in the series (e.g., 2011, 2016) and a clear recovery in 2018. This is especially remarkable for the low tourist season, with values in 2018 overcoming the values of 2007, and is also getting closer to the volumes consumed in the high season. The observed decreasing trend is, however, masking differences in the trends of consumed water by the different sectors (Figure 3C). The Kendall's coefficient showed a significant increase in water consumed by the commercial sector (i.e., ferries and cruisers) for both the low and 
high seasons (Figure 3C). The increase in water use recorded for the low season is considerable and is an indicator of how the number of cruises and ferries has grown in months like November, March and April during recent years. Unlike commercial water use, recreational, navy and mixed sectors showed either no trend or decreasing trends that were significant during the low tourist season.

\subsection{Water Withdrawal by Cruise Ships}

The evolution of movement of passengers has grown substantially since 2000, except for a remarkable decrease between 2007 and 2010 for ferry passengers and in 2012 for cruise passengers (Figure 4). In recent years, although the trend in passenger traffic has been positive, due in part to a boom in the cruise market, it is observable that the number of ferry passengers has not grown at the same rate. The decrease in water withdrawals since 2007 outlined in the above section can be partially explained by the important reduction in the number of ferry passengers. When the dynamic of passengers was compared with the water consumed in the commercial sector, the reduction between 2007 and 2010 was significant and could be a consequence of the decrease in the number of ferry ships and passengers. From 2010 onwards, water withdrawals in the sector increased, in general terms, with a positive relationship with the increase of cruise and ferry passengers in the last years. The important increase in number of cruise ships and recovery of the number of ferries seemingly has an impact on the water used in the Port of Palma.

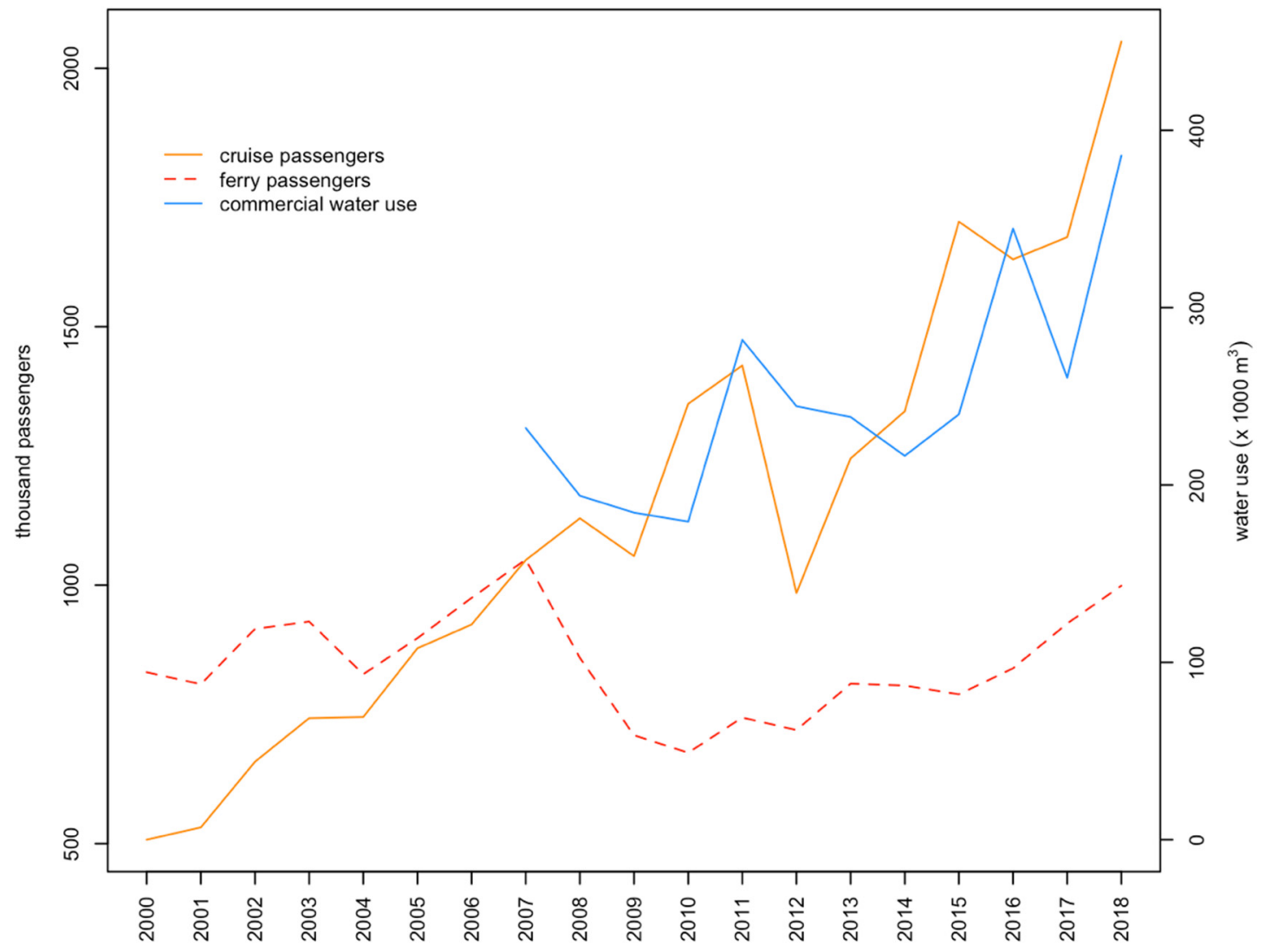

Figure 4. Historical series of dynamic of passengers and ships from cruisers and ferries, along with the water use in the port by the commercial sector.

Table 1 shows monthly water withdrawals by ship typology and number of ships for the year 2016 (data for other years were not available or not possible to obtain). Total water use in the Port of Palma was $627,300 \mathrm{~m}^{3}$. Half of this volume corresponds to consumption by merchant ships and from the mixed and commercial sectors. Seasonality was higher for the cruises and lowest for the merchants. In terms of water loaded by the different ships, there were three distinct categories: 
Table 1. Water withdrawals by merchants and cruise ships for the year 2016.

\begin{tabular}{|c|c|c|c|c|c|c|c|c|c|c|c|}
\hline Month & $\begin{array}{c}\text { Total Water } \\
\text { Withdrawals } \\
\text { Port of Palma, } \\
\text { m }^{3}\end{array}$ & $\begin{array}{c}\text { Total Water } \\
\text { Withdrawals by } \\
\text { Merchants Ships (Mixt } \\
\text { and Commercial } \\
\text { Sectors), } \mathrm{m}^{3}\end{array}$ & $\begin{array}{c}\text { Number of } \\
\text { Merchant Ships }\end{array}$ & $\begin{array}{c}\text { Average Water } \\
\text { Withdrawals by } \\
\text { Merchant Ship, } \\
\text { m }^{3}\end{array}$ & $\begin{array}{l}\text { Total Water } \\
\text { Withdrawals } \\
\text { by Cruise } \\
\text { Ship, } \mathrm{m}^{3}\end{array}$ & $\begin{array}{l}\text { Number of } \\
\text { Transit } \\
\text { Cruises }\end{array}$ & $\begin{array}{c}\text { Total Water } \\
\text { Withdrawals } \\
\text { by Transit } \\
\text { Cruise, } \mathrm{m}^{3}\end{array}$ & $\begin{array}{c}\text { Average Water } \\
\text { Withdrawals } \\
\text { by Transit } \\
\text { Cruise, } \mathrm{m}^{3}\end{array}$ & $\begin{array}{c}\text { Number of } \\
\text { Homeport } \\
\text { Cruises }\end{array}$ & $\begin{array}{c}\text { Total Water } \\
\text { Withdrawals } \\
\text { by Homeport } \\
\text { Cruise, } \mathrm{m}^{3}\end{array}$ & $\begin{array}{c}\text { Average Water } \\
\text { Withdrawals } \\
\text { by Homeport } \\
\text { Cruise, } \mathrm{m}^{3}\end{array}$ \\
\hline Jan & 47,080 & 40,969 & 162 & 252.9 & 0 & 8 & & 0 & 0 & & \\
\hline Feb & 22,870 & 14,324 & 165 & 86.8 & 2400 & 11 & 2400 & 218.2 & 0 & & \\
\hline March & 29,850 & 19,228 & 178 & 108.0 & 2930 & 16 & 2930 & 183.1 & 0 & & \\
\hline April & 25,200 & 12,753 & 182 & 70.1 & 6780 & 33 & 1870 & 56.7 & 12 & 4910 & 409.2 \\
\hline May & 46,390 & 14,871 & 182 & 81.7 & 19,760 & 42 & 4070 & 96.9 & 24 & 15,690 & 653.8 \\
\hline June & 57,700 & 27,852 & 202 & 137.9 & 18,320 & 28 & 2820 & 100.7 & 22 & 15,500 & 704.5 \\
\hline July & 74,810 & 38,402 & 213 & 180.3 & 19,300 & 38 & 2590 & 68.2 & 21 & 16,710 & 795.7 \\
\hline Aug & 62,770 & 29,223 & 204 & 143.3 & 19,630 & 41 & 5100 & 124.4 & 22 & 14,530 & 660.5 \\
\hline Sept & 98,710 & 69,699 & 181 & 385.1 & 14,550 & 41 & 3250 & 79.3 & 20 & 11,300 & 565.0 \\
\hline Oct & 55,050 & 23,845 & 170 & 140.3 & 20,710 & 48 & 870 & 18.1 & 32 & 19,840 & 620.0 \\
\hline Nov & 73,720 & 63,859 & 169 & 377.9 & 2780 & 32 & 330 & 10.3 & 4 & 2450 & 612.5 \\
\hline \multirow[t]{3}{*}{ Dec } & 33,150 & 27,432 & 163 & 168.3 & 0 & 7 & & 0 & 0 & & \\
\hline & 627,300 & 382,457 & & 177.7 & 127,160 & & 26,230 & 95.6 & & 100,930 & 627.6 \\
\hline & & & Standard deviation & 107.4 & & & & 62.7 & & & 104.8 \\
\hline
\end{tabular}


(1) the homeport cruises with the largest volumes, between $796 \mathrm{~m}^{3}$ in July to $409 \mathrm{~m}^{3}$ in April, and mean water withdrawals of $628 \mathrm{~m}^{3}$;

(2) the merchants, from mixed and commercial sectors, with mean water withdrawals of $178 \mathrm{~m}^{3}$ by ship, with a peak value of $545 \mathrm{~m}^{3}$; and

(3) the transit cruises, with a higher number than the homeport but with the lowest consumption. The mean volume recharged for the 2016 was $69 \mathrm{~m}^{3}$ with a peak of $218 \mathrm{~m}^{3}$.

The internal reports of the Port Authority of the Balearic Islands allocate a mean volume of $385 \mathrm{~m}^{3}$ for each homeport cruise arriving to the port. Results showed that the volume was about $20 \%$ higher.

\section{Discussion and Implications}

Water volumes used by the commercial sector in the Port of Palma showed a positive trend over the last 10 years. Although this evolution is marked by strong seasonality, water use also increased during the low tourist seasons. The increase of cruise passengers, and specifically the significant increase of homeport cruises, is remarkable. Data show that this type of cruise uses more water than other type of vessels in the Port of Palma. The increase in both the carrying capacity of cargo ships and the capacity of cruise ships explains the increase in commercial traffic and passenger numbers, without an increase of the number of ships. This is consistent with previous research, where the accessibility of tourist offerings is a crucial factor [31,34,35], and 'island fever' is a major influence for cruise passengers [36].

Homeports have a different socio-economic and environmental impact than transit cruise ships. On one hand, homeports have a more severe negative effect on the environment, as they require transport logistics to be considered (including airplanes, shuttles from airport-port-airport, more $\mathrm{CO}_{2}$ emissions derived from modes of transport, and water). On the other hand, most homeport passengers do not have time to visit the city, so the economic benefit is less than that of transit cruises. However, tour operators such as TUI GROUP are betting on consolidating the Port of Palma as a hub port. Palma has excellent air connections with the British and German markets; therefore, flight prices are much cheaper than other destinations such as Barcelona, with which Palma has a competitive homeport relationship [3].

Another reason for the increasing attractiveness of the Port of Palma for homeport cruises and for recharging water in their ships may be the water price. In 2016, the APB sold $1 \mathrm{~m}^{3}$ of water to cruise ships for $1.62 €$. Although the price increased to $2.62 € / \mathrm{m}^{3}$ in 2017 , it is still a very competitive price for cruise ships in comparison with other Spanish ports [37]. The APB is excluded from an increasing block system (the more you consume the more you pay), and it pays only $0.93 € / \mathrm{m}^{3}$ to the local water company [38].

The mean water volume loaded by each homeport cruise in 2016 (628,000 liters) can be used as a water withdrawal indicator when it is divided by the mean passenger number per cruise (the mean passenger number per cruise ship was 2202 [12]), giving a value of 285.5 liters loaded per passenger. If some cruise companies, for example TUI, estimate freshwater withdrawals of 162 liters per cruise passenger night, a value of 180 liters loaded per passenger can be established as a maximum freshwater volume allowed to load, and this can be considered as a reasonable recommendation to the water managers at the Port of Palma. In order to establish the most appropriate value, the Port Authority of the Balearic Islands should make public the water volumes loaded by all ships during the last years. Liters loaded by passenger seems an optimal water use indicator that can be used in other ports. This indicator could then be compared with volumes consumed by other touristic activities (like hotels), or with water withdrawals per capita among the local population, in order to identify potential conflicts and to establish priorities by the water managers.

The $380,000 \mathrm{~m}^{3}$ of water consumed by the commercial sector in 2018 is an important amount of water in the municipality of Palma. It represents $80,000 \mathrm{~m}^{3}$ more than the water consumed by 38 four-star hotels offering 6242 rooms per day in the municipality (including hotels in the city center and in the touristic area of Playa de Palma). In 2018 more than 29 million passengers passed through 
the airport of Palma. AENA, the airport operator in Spain, recognized total water withdrawals of $484,000 \mathrm{~m}^{3}$ in the airport in 2018. It is evident that the increasing cruise activity in the western Mediterranean ports has an impact on freshwater resources and especially on islands where water is scarce and intense droughts occur [20-22,39]. The threat of climate change, with longer and more intense dry periods, emphasizes the rational use of water for activities such as cruise ship tourism that has a growing social context in the Balearic Islands (e.g., more than 10,000 Majorcan residents signed a petition calling for a limit of one cruise ship a day docking in Palma, and there have been several anti-cruise ship protests).

Port authorities should be more transparent and publish the water volumes consumed by the different commercial activities, as a step in valuing the resource and improving the efficiency of its use. In this particular study, although the Port Authority shared the data, the main limitation was obtaining actual total water volumes used in the port. The Port Authority publishes water withdrawals in its sustainability reports that do not include the water sold to other ships, like cruises, but it was freshwater supplied by the water company to the Port of Palma and used. The autonomous government of the Balearic Islands asked the Port Authority of the Balearic Islands to regulate the number of cruise ships per day docking in Port of Palma and negotiate a moratorium with the major cruise lines, especially during the tourist season. The president of the Port Authority responded to the regional government, saying this would be not possible until 2022 due to reservations already made by some ship lines and for legal assurance. The same request for a cruise regulation at the Port of Palma was made by local associations and NGOs in 2018, with no answer.

It is unclear how this situation will be solved between the regional government and the Port Authority, but what is clear from this study is that the increasing homeport cruise ships are demanding more water every year and increasing the pressure on the already limited water resources of the island. In 2019, 598 cruise ships arrived in the Port of Palma, and it seems this value will be similar over the next two years, but probably with more passengers. In 2016, the number of cruises was 487. Water volumes loaded by ships will increase and will represent high pressure by this touristic sector on water demand in the city of Palma. Further research is needed in other Mediterranean ports to clarify the volumes of water loaded by cruises and reported as a water withdrawal indicator (liters loaded per passenger). Water prices established by each port authority should be published, as it seems that the price per $\mathrm{m}^{3}$ in the Port of Palma is one of the cheapest in the Mediterranean.

Furthermore, under climate change scenarios (less availability of freshwater in the Mediterranean region for upcoming decades [26,27]), and taking into account the projected occurrence of more frequent and severe drought episodes in the region, cruise activity in the Port of Palma must rely on stricter regulation and on the introduction of cruise traffic limitations. Otherwise, the continuation of this activity, as it is currently, may no longer be possible, since it will directly clash with water priority interests.

Author Contributions: Conceptualization, C.G. and D.T.; data curation, C.M.-R. and C.G.; formal analysis, C.M.-R., E.M.-T. and J.L.-L.; investigation, C.G.; writing-original draft preparation, C.G.; writing-review and editing, C.G., C.M.-R., E.M.-T., J.L.-L. and D.T. All authors have read and agreed to the published version of the manuscript.

Funding: This research received no external funding.

Acknowledgments: The Port Authority of the Balearic Islands kindly supplied all the water volumes consumed by the Port of Palma. We would like to acknowledge its support whenever it was needed, answering emails quickly and send the data. Special thanks goes to Julio Galán, Josep Aubareda, Jaime Gili and Jorge Martín. We are grateful to the anonymous reviewers and the editor Emmanuel Reynard for their constructive comments that helped improve the final manuscript.

Conflicts of Interest: The authors declare no conflicts of interest. 


\section{References}

1. ESPO Environmental Report 2018. EcoPortsinSights 2018. Available online: https://www.espo.be/media/ ESPOEnvironmentalReport2018.pdf (accessed on 10 March 2020).

2. Puig, M.; Wooldridge, C.; Michail, A.; Darbra, R.M. Current status and trends of the environmental performance in European ports. Environ. Sci. Policy 2015, 48, 57-66. [CrossRef]

3. Esteve-Perez, J.; Garcia-Sanchez, A. Dynamism patterns of western mediterranean cruise ports and the coopetition relationships between major cruise ports. Polish Marit. Res. 2018, 25, 51-60. [CrossRef]

4. Carić, H. Cruising Tourism Environmental Impacts: Case Study of Dubrovnik, Croatia. J. Coast. Res. 2011, 61, 104-113. [CrossRef]

5. Legoupil, T. Los conflictos que genera el turismo de cruceros en Barcelona y otros puertos Mediterráneos. Biblio 3W. Rev. Bibliogr. Geogr. Cienc. Soc. 2013, 18, 13.

6. Dragović, B.; Tzannatos, E.; Tselentis, V.; Meštrović, R.; Škurić, M. Ship emissions and their externalities in cruise ports. Transp. Res. Part D Transp. Environ. 2018, 61, 289-300. [CrossRef]

7. Carić, H. Challenges and prospects of valuation-Cruise ship pollution case. J. Clean. Prod. 2016, 111, 487-498. [CrossRef]

8. Deidun, A.; Vella, P. Marine Ecological Impact Considerations for Cruise Liner Facility Development at Two Coastal Sites in the Maltese Islands. J. Coast. Res. 2011, 61, 114-122. [CrossRef]

9. Asero, V.; Skonieczny, S. Cruise Tourism and Sustainability in the Mediterranean. Destination Venice. In Mobilities, Tourism and Travel Behavior-Contexts and Boundaries; InTechOpen limited: London, UK, 2018; pp. 93-106.

10. Marques, M. The Cruise Industry in the World. In Managing, Marketing, and Maintaining Maritime and Coastal Tourism; Mónica Morais de Brito, D.A., Patuleia, M., Eds.; IGI Global: Hershey, PA, USA, 2020; pp. $223-232$.

11. Rosa-Jiménez, C.; Perea-Medina, B.; Andrade, M.J.; Nebot, N. An examination of the territorial imbalance of the cruising activity in the main Mediterranean port destinations: Effects on sustainable transport. J. Transp. Geogr. 2018, 68, 94-101. [CrossRef]

12. Medcruise Cruise Activities in MedCruise Ports. Statistics Report 2018; MedCruise Association: Santa Cruz de Tenerife, Spain, 2019.

13. Karlis, T.; Polemis, D. Cruise homeport competition in the Mediterranean. Tour. Manag. 2018, 68, 168-176. [CrossRef]

14. Vega-Muñoz, A.; Arjona-Fuentes, J.M.; Ariza-Montes, A.; Han, H.; Law, R. In search of 'a research front' in cruise tourism studies. Int. J. Hosp. Manag. 2019, 102353. [CrossRef]

15. Papathanassis, A.; Beckmann, I. Assessing the "poverty of cruise theory" hypothesis. Ann. Tour. Res. 2011, 38, 153-174. [CrossRef]

16. Véronneau, S.; Roy, J. Global service supply chains: An empirical study of current practices and challenges of a cruise line corporation. Tour. Manag. 2009, 30, 128-139. [CrossRef]

17. Bonilla-Priego, M.J.; Font, X.; del Pacheco-Olivares, M.R. Corporate sustainability reporting index and baseline data for the cruise industry. Tour. Manag. 2014, 44, 149-160. [CrossRef]

18. TOUI Group 2018 Sustainability Report. Available online: https:/www.tuigroup.com/damfiles/default/ tuigroup-15/de/nachhaltigkeit/berichterstattung-downloads/2019/nachhaltigkeitsbericht-de-en/TUI_ CSR18_EN.pdf-1e195dc4f0aff3763334c790e5417049.pdf (accessed on 9 March 2020).

19. Stefanidaki, E.; Lekakou, M. Cruise carrying capacity: A conceptual approach. Res. Transp. Bus. Manag. 2014, 13, 43-52. [CrossRef]

20. Viola, F.; Sapiano, M.; Schembri, M.; Brincat, C.; Lopez, A.; Toscano, A.; Diamadopoulos, E.; Charalambous, B.; Molle, B.; Zoumadakis, M.; et al. The state of water resources in major Mediterranean islands. Water Resour. 2014, 41, 639-648. [CrossRef]

21. Lorenzo-Lacruz, J.; Moran-Tejeda, E. Spatio-temporal patterns of meteorological droughts in the Balearic Islands (Spain). Geogr. Res. Lett. 2016, 42, 49. [CrossRef]

22. Lorenzo-Lacruz, J.; Garcia, C.; Morán-Tejeda, E. Groundwater level responses to precipitation variability in Mediterranean insular aquifers. J. Hydrol. 2017, 552. [CrossRef]

23. Hof, A.; Blázquez-Salom, M. Changing tourism patterns, capital accumulation, and urban water consumption in Mallorca, Spain: A sustainability fix? J. Sustain. Tour. 2015, 23, 770-796. [CrossRef] 
24. Deyà-Tortella, B.; Garcia, C.; Nilsson, W.; Tirado, D. Analysis of Water Tariff Reform on Water Consumption in Different Housing Typologies in Calvi. Water 2017, 9, 425. [CrossRef]

25. Garcia, C.; Servera, J. Impacts of tourism development on water demand and beach degradation on the island of Mallorca (Spain). Geogr. Ann. Ser. A-Phys. Geogr. 2003, 85, 287-300. [CrossRef]

26. Giorgi, F.; Lionello, P. Climate change projections for the Mediterranean region. Glob. Planet. Chang. 2008, 63, 90-104. [CrossRef]

27. García-Ruiz, J.M.; López-Moreno, J.I.; Vicente-Serrano, S.M.; Lasanta-Martínez, T.; Beguería, S. Mediterranean water resources in a global change scenario. Earth-Sci. Rev. 2011, 105, 121-139. [CrossRef]

28. Diffenbaugh, N.S.; Pal, J.S.; Giorgi, F.; Gao, X. Heat stress intensification in the Mediterranean climate change hotspot. Geophys. Res. Lett. 2007, 34,1-6. [CrossRef]

29. Memoria de Sostenibilidad. Available online: https://www.portsdebalears.com/es/memoria-sostenibilidad2018 (accessed on 27 January 2020).

30. IBESTAT Indicador de Pressió Humana. Available online: https://ibestat.caib.es/ibestat/estadistiques/ poblacio/estudis-demografics/indicador-pressio-humana-iph/e91ffb58-6bdd-457c-bd25-ed2a201f57ae (accessed on 10 March 2020).

31. Gui, L.; Paolo Russoz, A. Cruise ports: A strategic nexus between regions and global lines-evidence from the mediterranean. Marit. Policy Manag. 2011. [CrossRef]

32. IGN Plan Nacional de Ortofotografía Aérea. Available online: https://pnoa.ign.es/ortofotos (accessed on 27 January 2020).

33. Yue, S.; Pilon, P.; Phinney, B. Canadian streamflow trend detection: Impacts of serial and cross-correlation. Hydrol. Sci. J. 2003, 48, 51-64. [CrossRef]

34. Bagis, O.; Dooms, M. Turkey's potential on becoming a cruise hub for the East Mediterranean Region: The case of Istanbul. Res. Transp. Bus. Manag. 2014, 13, 6-15. [CrossRef]

35. Pino, G.; Peluso, A.M. The development of cruise tourism in emerging destinations: Evidence from Salento, Italy. Tour. Hosp. Res. 2018, 18, 15-27. [CrossRef]

36. Castillo-Manzano, J.I.; Fageda, X.; Gonzalez-Laxe, F. An analysis of the determinants of cruise traffic: An empirical application to the Spanish port system. Transp. Res. Part E 2014, 66, 115-125. [CrossRef]

37. Boulben el Ghachaoui, S. Análisis Económico y Comparativo de la Producción de Agua Dulce Mediante un Generador a Bordo de un Buque Mercante; Universitat Politècnica de Catalunya: Barcelona, Spain, 2013.

38. EMAYA Water Tariffs. Available online: http://www.caib.es/eboibfront/es/2016/10595/589329/publicacionnuevas-tarifas-de-emaya-2017 (accessed on 31 January 2020).

39. Ramis, C.; Romero, R.; Homar, V.; Alonso, S.; Jansà, A.; Amengual, A. On the drought in the Balearic Islands during the hydrological year 2015-2016. Nat. Hazards Earth Syst. Sci. 2017, 17, 2351-2364. [CrossRef] 